\title{
PENERJEMAHAN TEKS THE GOSPEL ACCORDING TO MATTHEW KE DALAM TEKS BAHASA INDONESIA
}

\author{
Bena Yusuf Pelawi \\ Fakultas Sastra Universitas Kristen Indonesia Jakarta \\ email: sylvie_surya@yahoo.co.id
}

\begin{abstract}
Abstrak
Penelitian ini bertujuan mendeskripsikan teknik, metode, dan ideologi penerjemahan teks The Gospel According to Matthew ke dalam teks bahasa Indonesia. Penelitian menggunakan metode deskriptif kualitatif. Sumber data adalah teks The Gospel According to Matthew, pasal 5-7 dan terjemahannya dalam bahasa Indonesia. Hasil penelitian sebagai berikut. Pertama, terdapat sembilan teknik penerjemahan, yakni (a) modulasi, (b) transposisi, (c) amplifikasi, (d) harfiah, (e) penambahan, (f) penghilangan, (g) peminjaman alamiah, (h) reduksi, dan (i) generalisasi. Kedua, terdapat empat metode penerjemahan, yakni (a) bebas, (b) komunikatif, (c) adaptasi, dan (d) harfiah. Ketiga, terdapat dua ideologi penerjemahan, yaitu: (a) foreignisasi yang berorientasi pada bahasa dan budaya bahasa sumber, dan (b) domestikasi yang berorientasi pada bahasa dan budaya bahasa sasaran. Secara umum penerjemahan cenderung menggunakan teknik, metode, dan ideologi yang berorientasi pada bahasa dan budaya sasaran. Orientasi pada bahasa dan budaya sasaran dapat menghasilkan terjemahan yang akurat, berterima, dan memiliki tingkat keterbacaan tinggi.
\end{abstract}

Kata kunci: teknik penerjemahan, metode penerjemahan, ideologi penerjemahan, keterbacaan, keberterimaan, keakuratan

\section{THE TRANSLATION OF THE GOSPEL ACCORDING TO MATTHEW INTO AN INDONESIAN LANGUAGE TEXT}

\begin{abstract}
This study aims to describe techniques, methods, and ideologies in the translation of The Gospel According to Matthew into an Indonesian language text. It employed the qualitative descriptive method. The data source was The Gospel According to Matthew, articles 5-7 and its Indonesian translation. The findings are as follows. First, there are nine translation techniques, i.e.: (a) modulation, (b) transposition, (c) amplification, (d) literal translation, (e) addition, (f) omission, (g) natural borrowing, (h) reduction, and (i) generalization. Second, there are four translation methods, i.e.: (a) free translation, (b) communicative translation, (c) adaptation, and (d) literal translation. Third, there are two translation ideologies, i.e.: (a) foreignization oriented to the source language and culture, and (b) domestication oriented to the target language and culture. In general, the translation tends to employ techniques, methods, and ideologies oriented to the target language and culture. The orientation to the target language and culture can result in a translation which is accurate, acceptable, and highly readable.
\end{abstract}

Keywords: translation techniques, translation methods, translation ideologies, readable, acceptable, accurate 


\section{PENDAHULUAN}

Cara seseorang menginterpretasikan sebuah ungkapan berlatar budaya asing dipengaruhi oleh nilai-nilai yang sudah dijiwainya sebagai bagian dari kebudayaannya. Jika seseorang dihadapkan pada budaya yang belum dikenal, ia cenderung menilai kebudayaan itu dengan 'kaca mata' budayanya sendiri (Ihroni, 1984:57). Pendapat itu tidak berlebihan karena dalam kehidupan masyarakat terdapat sistem nilai budaya, dalam sistem nilai budaya itu terdapat norma-norma, dan norma-norma itu mempengaruhi pola pikir, serta pola pikir itulah yang melandasi pola tindakan (Sayogya, 1982:99).

Di antara banyak sumber tatanilai yang ada di masyarakat, Alkitab adalah salah satu yang spesifik dan bernilai kualitatif. Alkitab tidak saja merupakan sumber tatanilai dan tatanorma yang urgensinya sudah jelas di masyarakat, tetapi juga merupakan karya terjemahan yang sarat dengan muatan nilai sosiokultural, yaitu nilai budaya religi. Brislin (1976:279) menyatakan bahwa Alkitab bukan buku biasa. Di dalamnya terdapat begitu banyak karya literer yang variatif seperti legenda, sage, puisi, rumusan hukum, biografi, dan surat yang ditulis dalam satu rangkaian sejarah yang panjang.

Sebagai sumber acuan tata nilai, Alkitab dipakai masyarakat dari zaman ke zaman, berjalan menurut garis sejarah. Alkitab adalah buku yang paling banyak diterbitkan dan paling luas dibaca di dunia. Alkitab adalah buku yang paling banyak diterjemahkan di planet ini (Kennedy \& Jerry Newcombe, 1999: 18). Menurut catatan resmi Perserikatan Lembagalembaga Alkitab Sedunia (United Bible Sicieties), pada tahun 1800 hanya ada 68 bahasa di dunia yang memiliki terjemahan Alkitab, Perjanjian Baru atau salah satu buku dari Alkitab. Akan tetapi, pada akhir tahun 1992, telah tersedia terjemahan Alkitab dalam 2012 bahasa di dunia dengan perincian sebagai berikut: (a) 333 bahasa memiliki terjemahan Alkitab, (b) 769 bahasa memiliki terjemahan Perjanjian Baru, dan (c) 916 bahasa memiliki terjemahan salah satu buku dari Alkitab. Termasuk di dalamnya terjemahan Alkitab dalam 134 bahasa di Indonesia, yang terdiri atas 17 Alkitab, 27 Perjanjian Baru, dan 90 bagian Alkitab. Ini berarti Alkitab merupakan satu-satunya buku yang paling banyak diterjemahkan di jagad ini. Bahkan pada saat ini, 110 Lembaga Alkitab di seluruh dunia yang tergabung dalam United Bible Societies, berpartisipasi aktif dalam usaha penerjemahan Alkitab ke dalam 624 bahasa di dunia, termasuk di dalamnya 426 bahasa yang sebelumnya tidak pernah memiliki terjemahan Alkitab maupun bagiannya (Latuihamallo, 1994: 11).

Alkitab digunakan oleh bangsabangsa di dunia yang berbeda budaya dan bahasanya, Dengan demikian penerjemahannya pun akhirnya tidak dapat dielakkan. Di Indonesia, hakikat misi Lembaga Alkitab Indonesia secara universal dalam menerjemahkan Alkitab adalah untuk menyebarkan Firman Allah secara efektif dan bermakna seluas-luasnya dengan bahasa dan media yang mudah dipahami dan dimengerti. Melalui penerjemahan yang setia kepada naskah asli ke dalam bahasa ibu diharapkan para pengguna bahasa itu dapat menerima dengan jelas isi pesan firman tersebut (Supardan, 2004: $x$-xi).

Pada kenyataannya, mayoritas umat Kristen di Indonesia tidak dididik secara khusus untuk membaca Kitab Suci dalam bahasa-bahasa 'asli', yaitu Ibrani, Aram, dan Yunani. Oleh sebab itu, untuk membaca dan menghayati Firman Tuhan, mereka pada umumnya bergantung pada terjemahan-terjemahan yang tersedia dalam berbagai bahasa. Kenyataan ini mempunyai implikasi yang penting dalam pemahaman umat akan Firman Allah. Artinya, unsur-unsur makna yang terkandung dalam teks-teks sumber jelas telah melalui suatu 'saringan' awal para 
penerjemah sebelum dituangkan ke dalam bahasa sasaran.

Jika tugas menerjemahkan secara sederhana diartikan sebagai mengalihbahasakan, mengungkapkan kembali apa yang dimaksud dalam teks sumber, maka hasil terjemahan itu mau tidak mau merupakan pengungkapan kembali pesan atau isi menurut apa yang diketahui dan dipahaminya oleh penerjemah terhadap teks sumber. Karena itu, hasil terjemahan seseorang sangat tergantung pada beberapa faktor. Misalnya, kompetensi penerjemah dalam bahasa teks sumber dan bahasa sasaran, keterampilan penerjemah mengungkapkan kembali apa yang dipahaminya dari teks sumber, asumsiasumsi penerjemah mengenai sasaran dari terjemahannya, atau pun jenis sastra (genre) bahan yang diterjemahkannya (Tjen, 2004:88).

Mengenai kualifikasi penerjemah, Latuihamallo (1994:11) mengungkapkan bahwa kualitas penerjemah yang dipekerjakan Nederlands Bijbelgenootshap (NBG) nampaknya ada perbedaan yang mendasar antara abad ke-19 dan abad ke20. Pada abad ke-19, calon-calon penerjemah tidak memiliki kualifikasi akademik secara khusus. Setiap orang yang terpanggil untuk pekerjaan itu mendapat sekedar kursus mengenai Alkitab dan mereka yang pernah mendapat pendidikan nonakademik dalam bidang teologi diprioritaskan. Sejak akhir abad ke-19, kebijakan itu diubah dengan mengharuskan para calon penerjemah mendapatkan pendidikan akademik dalam bidang kebahasaan di Universitas Leiden. Lembaga NBG juga mengangkat beberapa ahli linguistik untuk mengawasi pekerjaan para penerjemah di Indonesia. Salah seorang ahli linguistik yang sangat penting dalam hal ini adalah H. Kraemer (1888-1965).

Di Indonesia, Lembaga Alkitab Indonesia (LAI) yang merupakan kelanjutan dari Nederlands Bijbelgenootschap (NBG) bertanggung jawab atas semua aspek kegiatan, termasuk penerjemahan. Komisi Penerjemah menjadi cukup kuat dan tugas utama komisi ini adalah merampungkan penerjemahan Alkitab ke dalam bahasa Indonesia yang telah lama terbengkalai. Dengan demikian jelas bahwa bahasa, khususnya linguistik mempunyai peran penting dalam penerjemahan. Itulah sebabnya dalam sudut pandang linguistik terapan, penerjemahan Alkitab bisa menjadi substansi penting untuk dicermati. Lebih lanjut, dengan mempertimbangkan begitu variatifnya isi Alkitab, upaya pencermatan terhadap terjemahannya bisa menjadi model investigasi ilmiah bagi studi linguistik, khususnya bidang penerjemahan.

Di dalam penerjemahan Alkitab, terdapat masalah-masalah penting yang harus dipecahkan. Kesenjangan waktu, perbedaan sistem bahasa dan perbedaan budaya sumber (BSu) dan budaya dan bahasa sassaran (BSa) dapat menimbulkan masalah-masalah dalam penerjemahan. Istilah-istilah budaya biasanya sangat sukar untuk diterjemahkan dari bahasa sumber ke bahasa sasaran. Padahal penerjemahan yang kurang tepat beresiko fatal karena Alkitab banyak sekali pembacanya tanpa memandang usia, jenis kelamin, ras, suku, dan status sosial. Hal itu sejalan dengan apa yang diungkapkan seorang penerjemah bahasa Jawa, P.Jansz (1851 di Batavia) sebagai berikut: "Jadi tugas saya bukanlah mengalihkan cara berbicara Yunani atau Ibrani ke dalam bahasa Jawa, tetapi men-Jawa-kan bahasa-bahasa itu."

Ahli penerjemah, Kraemer, menyatakan bahwa menerjemahkan adalah mencipta kembali, membuat sebuah buku berbicara menurut kebiasaan berbahasa dari bahasa lain. Akan tetapi, untuk menerjemahkan Alkitab ada prasyarat lain lagi. "Pekerjaan menerjemahkan Alkitab mengandung kesulitan-kesulitan khusus karena sifat sakral dari Alkitab menuntut kecermatan khusus yang harus diupaya- 
kan dengan penuh kesadaran."Tidak semua penerjemah ternyata berhasil mencapainya (Latuihamallo, 1994: 5-6).

Dengan demikian dapat dikatakan untuk memperoleh hasil terjemahan yang baik dibutuhkan pula proses penerjemahan yang baik. Larson (1984:6) memberikan kriteria mengenai penerjemahan yang berkualitas. Penerjemahan yang paling baik adalah yang menggunakan bentuk bahasa yang wajar dalam bahasa sasaran (BSa). Suatu terjemahan harus mampu mengkomunikasikan makna yang sama seperti halnya makna yang dimengerti oleh pembaca dalam bahasa sumber (BSu).

Dari sudut pandang penerjemah, penerjemahan adalah proses pengambilan keputusan dalam komunikasi interlingual, suatu komunikasi verbal yang melibatkan dua bahasa yang berbeda, yaitu bahasa sumber dan bahasa sasaran. Dalam kaitan itu, semua keputusan yang diambilselalu dilandasi oleh ideologi yang dianutnya. Dalam konteks penerjemahan, ideologi yang dimaksud adalah sistem kepercayaan, cara pandang, budaya, dan norma yang dimiliki penerjemah yang akan mempengaruhi perilaku penerjemahannya. Jika penerjemah memandang bahwa budaya bahasa sumber perlu dipertahankan dalam terjemahan, misalnya, itu berati dia menganut idelogi foreignisasi. Sebaliknya, jika dia memandang bahwa suatu terjemahan harus lebih mementingkan budaya bahasa sasaran, dia menganut ideologi domestikasi.

Ideologi penerjemahan tersebut merupakan konsep yang relatif. Artinya, bahwa sistem kepercayaan atau budaya yang dianut oleh penulis teks bahasa sumber belum tentu sama dengan ideologi yang dianut oleh penerjemah. Sebaliknya, ideologi penerjemah belum tentu sesuai dengan ideologi yang dimiliki oleh pembaca teks bahasa sasaran.Dalam praktek penerjemahan yang sesungguhnya, ideologi penerjemah harus disesuaikan dengan ideologi pembaca teks bahasa sasaran agar terjemahannya dapat diterima pembaca teks bahasa sasaran.

Ideologi yang dianut oleh penerjemah berpengaruh pada cara dia dalam menentukan metode penerjemahan yang akan diterapkannya dalam menerjemahkan suatu teks. Jika penerjemah menganut ideologi foreignisasi, maka dia dapat menentukan salah satu dari beberapa metode penerjemahan, seperti metode penerjemahan kata demi kata, harfiah, setia, dan semantik. Sebaliknya, apabila penerjemah menganut ideologi domestikasi, maka metode penerjemahan yang dipilihnya akan berkisar di antara metode adaptasi, bebas, idiomatis, dan komunikatif. Ideologi penerjemahan juga sangat berpengaruh pada proses pemadanan. Ideologi foreignisasi cenderung menggunakan padanan formal, sedangkan ideologi domestikasi cenderung pada penggunaan padanan dinamis.

Selanjutnya, ideologi penerjemahan dan metode penerjemahan akan menuntun penerjemah dalam menetapkan teknik penerjemahan, sebagai realisasi dari strategi penerjemahan yang diterapkannya dalam proses penerjemahan. Suatu terjemahan yang menggunakan banyak kata pinjaman, merupakan pertanda bahwa penerjemah yang menghasilkan terjemahan itu telah menerapkan padanan formal atau metode penerjemahan harfiah dan dapat diduga bahwa penerjemah merupakan penganut ideologi foreignisasi.

Dengan demikian, ketiga komponen di atas, yakni ideologi penerjemahan, metode penerjemahan, dan teknik penerjemahan akan berdampak pada kualitas terjemahan. Kualitas terjemahan ditentukan berdasarkan keakuratan pesan (accuracy in content), keberterimaan (acceptability), dan keterbacaan (readability) terjemahan. Keempat komponen ini mempunyai hubungan timbal balik satu sama lain. Penelitian ini akan mendeskripsikan dan mengkaji ideologi penerjemahan pada tataran super makro, metode pener- 
jemahan pada tataran makro, dan teknik penerjemahan serta dampaknya terhadap kualitas terjemahan yang mencakup tingkat keakuratan pesan, keberterimaan, dan keterbacaan terjemahan.

Menurut Holy Bible (Alkitab) yang diterbitkan oleh Lembaga Alkitab Indonesia, Jakarta pada tahun 2009, kitab Injil bukanlah biografi. Kitab tersebut menceritakan kehidupan dan pengajaran Yesus, tetapi juga menggambarkan siapa Yesus dan apa yang dilakukan-Nya bagi dunia. Beberapa penulis kitab Injil ingin mengatakan sesuatu yang khusus tentang arti Yesus bagi dunia dan masing-masing memiliki bagian yang disusun berdasarkan tema yang dikembangkannya. Kitabkitab Injil berisi informasi sejarah, tetapi informasi tersebut selalu digunakan penulis untuk menunjukkan bahwa Yesus adalah Anak Allah dan Juruselamat dunia.

Ada empat kitab Injil, yaitu Injil Matius, Markus, Lukas, dan Yohanes. Injil Matius, Markus, dan Lukas disebut Injil-Injil Sinoptik. Kitab-kitab tersebut pada umumnya mengikuti sebuah iktisar atau garis-garis besar yang sama. Ketiga kitab itu dapat dipelajari secara pararel, karena ketiganya memiliki garis besar yang sama, menggunakan beberapa kata yang sama, dan muatan peristiwa yang sama. Beberapa penelitian alkitab moern didasarkan atas asumsi bahwa Kitab Matius dan Lukas menggunakan Kitab Markus sebagai sumber utama dan garis besarnya. Selanjutnya, Kitab Yohanes berbeda dengan kitab- kitab Injil lainnya. Kitab Yohanes tidak mengikuti garis besar yang sama, menggambarkan tiga tahun masa pelayanan Yesus, bukan satu tahun, dan berisi refleksi yang dalam mengenai makna pribadi Yesus, bukan ucapan-ucapan singkat dan perumpamaan-perumpamaan.

Markus mungkin merupakan kitab Injil yang tertua. Menurut tradisi, kitab Markus ditulis di Roma oleh Yohanes
Markus dan berisi kenangan Petrus. Penyaliban dan kebangkitan merupakan kunci utama untuk memahami siapa Yesus itu, dan hampir separuh lebih dari kitab Injil ini menceritakan peristiwa tersebut. Kitab Markus tidak dimulai dengan cerita tentang kelahiran, melainkan dimulai dengan kisah Yohanes Pembaptis.

Matius dimulai dengan menempatkan Yesus dalam seluruh cerita tentang penyelamatan. Yesus adalah keturunan Abraham dan keturunan Daud, memenuhi seluruh janji Allah kepada umat-Nya. Materi pengajaran dalam kitab Matius dibagi dalam lima bagian besar dan bagian yang paling dikenal ialah Khotbah di Bukit. Banyak yang mengatakan bahwa kitab Matius memandang Yesus sebagai Nabi Musa kedua yang memberikan sebuah Taurat baru kepada umat-Nya.

Lukas memberikan perhatian pada golongan masyarakat marginal dan terbuang, terutama perempuan dan orangorang miskin. Kitab ini dimulai dengan cerita kelahiran Yohanes Pembaptis dan Yesus. Kitab Lukas merupakan satusatunya kitab yang bercerita tentang Yesus di antara kelahiran dan pelayanan-Nya, keberadaan-Nya di Bait Allah saat berusia dua belas tahun. Beberapa cerita perumpamaan yang terkenal - orang Samaria yang baik hati, anak yang hilang, orang kaya dan Lazarus - hanya ditemukan dalam kitab Lukas.

Yohanes adalah kitab yang kurang berisi cerita dan bahkan tidak ada perumpamaan di dalamnya, tetapi merupakan rangkaian refleksi yang dalam mengenai Yesus sebagai Anak Allah. Kitab ini dimulai dengan sebuah nyanyian puji-pujian tentang "Sabda" yang tak lain adalah Allah dan menjadi manusia untuk menyelamatkan dunia. Sabda itu adalah Yesus. Kitab Yohanes juga berisi berbagai kejadian menakjubkan sebagai tanda penting yang menunjuk kepada Yesus. Pernyataan-pernyataan "Aku ada" mengekspresikan apa yang Yesus mak- 
sudkan dalam serangkaian metafora yang mencolok.

Dari keempat Injil tersebut di atas, Injil Matius menampilkan materi pengajaranyang dibagi dalam lima bagian besar dan bagian yang paling dikenal ialah Khotbah di Bukit. Berdasarkan alasan inilah maka penelitian ini memutuskan untuk meneliti Injil Matius, khususnya Khotbah di Bukit yang lebih menekankan pada pengajaran yang merupakan unsur penting di dalam sebuah kitab suci.

Dalam penelitian ini, penerjemahan Khotbah di Bukit (Pasal 5-7) dalam Injil Matius akan diteliti dengan mendeskripsikan teknik penerjemahan pada tataran mikro, dilanjutkan dengan mendeskripsikan metode penerjemahan pada tataran makro dan ideologi penerjemahan pada tataran supermakro. Lebih lanjut, penelitian ini akan mengkaji dampak ketiga aspek tersebut terhadap kualitas produk terjemahan yang mencakup tingkat keakuratan pesan, keberterimaan, dan keterbacaan produk terjemahan.

\section{METODE}

Sumber data pada penelitian ini adalah teks The Gospel According to Matthew (pasal 5-7) dan terjemahannya dalam bahasa Indonesia yang diterjemahkan dan diterbitkan oleh Lembaga Alkitab Indonesia pada tahun 2009. Strategi penelitian yang digunakan dalam penelitian adalah studi kasus. Secara khusus penelitian ini disebut dengan studi kasus terpancang atau embedded case study. Kasus-kasus dalam penelitian ini adalah terjemahan kata, frasa, klausa, kalimat, dan teks, kemudian mendeskripsikan dan menganalisis teknik, metode, dan ideologi penerjemahan yang diterapkan serta dampak ketiganya terhadap kualitas terjemahan yang mencakup tingkat keakuratan pesan, keterbacaan, dan keberterimaan terjemahan.

Dalam penelitian ini digunakan teknik cuplikan. Cuplikan yang diambil bersifat selektif atau purposive sampling technique.
Artinya, bagian yang dicuplik mengarah pada pemilihan kasus yang diteliti dalam penelitian ini, yaitu teknik, metode, ideologi penerjemahan dan dampaknya terhadap kualitas terjemahan.

Teknik pengumpulan data dalam penelitian ini adalah metode simak-catat dan wawancara. Dalam simak-catat, peneliti mencatat, menganalisis data yang ada. Analisis data menggunakan model teknik komparatif, yaitu membandingkan antara bahasa sumber dan bahasa sasaran dengan melihat penerapan: (1) teknik penerjemahan, (2) metode penerjemahan, (3) ideologi penerjemahan, dan 4) dampak penerapan ketiganya terhadap kualitas terjemahan yang mencakup: (a) keakuratan pesan, (b) keberterimaan, dan (c) keterbacaan terjemahan.

\section{HASIL DAN PEMBAHASAN}

Sesuai dengan tujuan penelitian, pada bagian ini disajikan hasil dan pembahasan penelitian yang mencakup empat hal, yaitu: (1) teknik penerjemahan; (2) metode penerjemahan; (3) ideologi penerjemahan; dan (4) dampak teknik, metode, dan ideologi penerjemahan terhadap hasil terjemahan. Uraian selengkapnya disajikan dalam subbab berikut.

\section{Teknik Penerjemahan}

Pemaparan tentang teknik penerjemahan dilakukan terlebih dahulu sebelum pengidentifikasian terhadap metode dan ideologi penerjemahan yang digunakan. Alasan yang mendasari adalah bahwa metode penerjemahan yang berada pada tataran makro dan ideologi penerjemahan yang berada pada tataran supermakro akan dapat diketahui kalau teknik penerjemahan yang berada pada tataran mikro sudah teridentifikasi terlebih dahulu.

Hasil analisis data ditemukan ada sembilan teknik dalam penerjemahan teks The Gospel According to Matthew ke dalam teks bahasa Indonesia. Kesembilan teknik yang dimaksud, yaitu: (a) modulasi, (b) 
transposisi, (c) amplifikasi, (d) harfiah, (e) penambahan, (f) penghilangan, (g) peminjaman alamiah, (h) reduksi, dan (i) generalisasi. Dalam menerjemahkan teks sumber, penerjemah menerapkan satu teknik penerjemahan (teknik tunggal), dua teknik penerjemahan (teknik kuplet), tiga teknik penerjemahan (teknik triplet), dan empat teknik penerjemahan (teknik kuartet).

\section{Teknik Penerjemahan Tunggal}

Teknik tunggal berarti penerjemah hanya menggunakan satu teknik terjemahan di antara sembilan teknik yang ada. Hasil analisis data ditemukan penerjemah menerapkan teknik tunggal pada 51 data sumber dengan enam varian teknik tunggal, yaitu modulasi, penghilangan, harfiah, penambahan, amplifikasi, dan transposisi (lihat Tabel 1).

Tabel 1. Teknik Penerjemahan Tunggal

\begin{tabular}{clc}
\hline Teknik & Varian Teknik Tunggal & Jumlah \\
\hline Tunggal & Modulasi & 24 \\
& Penghilangan & 10 \\
& Harfiah & 6 \\
& Penambahan & 4 \\
& Amplifikasi & 4 \\
& Transposisi & 3 \\
& Jumlah & 51 \\
\hline
\end{tabular}

Modulasi (modulation) adalah teknik penerjemahan dengan mengubah sudut pandang, fokus atau kategori kognitifpenerjemah dalam kaitannya dengan teks sumber. Perubahan sudut pandang tersebut dapat bersifat leksikal atau struktural. Teknik modulasi seperti tampak pada contoh data berikut.

$\begin{array}{lll}\text { Data } & \text { Bahasa Sumber } & \text { Bahasa Sasaran } \\ 06 & \text { Blessed are those } & \text { Berbahagialah } \\ & \begin{array}{ll}\text { who mourn, for } \\ \text { they shall be }\end{array} & \text { orang yang } \\ \text { comforted. } & \text { kerdukacita, } \\ & & \text { akan dihibur. }\end{array}$

Pada terjemahan tersebut terjadi perubahan sudut pandang bersifat leksikal, seperti blessed yang berarti 'diberkati' dialihkan ke dalam bahasa sasaran menjadi 'berbahagialah'; those yang dalam konteks ini dapat berarti 'mereka' diterjemahkan menjadi 'orang'. Perubahan sudut pandang yang bersifat leksikal ini dilakukan dengan harapan terjemahan dapat berterima bagi pembaca BSa.

Penghilangan (deletion) merupakan salah satu teknik penerjemahan yang diwujudkan dengan menghilangkan unsur bahasa sumber dari teks bahasa sasaran. Penghilangan unsur bahasa sumber tersebut pada umumnya disebabkan oleh ketiadaan padanan gramatikal. Pada konteks yang seperti itu, penghilangan tersebut bersifat wajib (obligatory) agar terjemahan yang dihasilkan tidak menyalahi kaidah bahasa sasaran. Di samping itu, penghilangan unsur bahasa sumber dari teks bahasa sasaran dapat pula dilakukan untuk menghindari pengulangan kata yang sama. Pada konteks ini penghilangan bersifat bebas (optional). Namun, acapkali teknik penghilangan ini digunakan sebagai "excuse" oleh penerjemah untuk menutupi ketidakmampuannya dalam menemukan padanan bahasa sumber dalam bahasa sasaran.

Pada tataran frasa, klausa atau kalimat, penghilangan dapat bersifat sebagian (partial) atau menyeluruh (total). Sesuai dengan namanya, penghilangan sebagian merujuk pada penghilangan bagian frasa, klausa, atau kalimat. Sebaliknya, penghilangan menyeluruh merujuk pada penghilangan keseluruhan unsur-unsur yang terdapat dalam frasa, klausa, atau kalimat yang bersangkutan.

Dalam data penelitian ini, penerjemah menerapkan teknik penghilangan total/ menyeluruh. Contoh berikut menegaskan hal tersebut.

Data Bahasa Sumber Bahasa Sasaran

025 Murder Begins in the Heart 
Penulis berkeyakinan bahwa informasi yang terkandung dalam frasa, klausa, dan kalimat sumber sangat penting. Oleh sebab itu, data sumber tersebut seharusnya diterjemahkan ke dalam bahasa sasaran. Data sumber Murder Begins in the Heart yang merupakan sub-judul tidak seharusnya dihilangkan karena penghilangan data ini dalam BSa tentunya akan menyebabkan tidak lengkapnya pesan yang diterima oleh pembaca BSa.

Harfiah merupakan teknik penerjemahan dengan menerjemahkan suatu ungkapan secara harfiah. Teknik ini mempersyaratkan pemadanan leksikal yang masih terikat dengan bahasa sumber tetapi susunan leksikal yang membentuk suatu ungkapan sudah disesuaikan dengan kaidah bahasa sasaran. Perthatikan contoh berikut.

\section{Data Bahasa Sumber Bahasa Sasaran \\ 083 "For where your Karena di mana treasure is, there hartamu berada, your heart will di situ juga be also. hatimu berada.}

Dalam menerjemahkan data tersebut, penerjemah melakukan pemadanan leksikal yang masih terikat dengan bahasa sumber walaupun susunan leksikal yang membentuk suatu ungkapan sudah disesuaikan dengan kaidah bahasa sasaran. Hal itu terlihat ketika penerjemah mengalihkan for where your treasure is menjadi 'karena di mana hartamu berada', there your heart will be also menjadi 'di situ juga hatimu berada'.

Penambahan adalah teknik penerjemahan yang digunakan oleh seorang penerjemah dengan melakukan penambahan makna ke dalam bahasa sasaran. Penambahan makna yang dimaksud adalah kehadiran satu atau beberapa kata yang dimaksudkan untuk lebih memperjelas maksud penulis asli. Penambahan unsur-unsur leksikal seperti ini lazim disebut sebagai eksplisitisasi yang ber- tujuan membuat sesuatu yang implisit dalam bahasa sumber menjadieksplisit dalam bahasa sasaran. Tujuan akhirnya adalah untuk menghasilkan terjemahan yang tidak taksa dan mudah dipahami oleh pembaca sasaran. Perhatikan contoh berikut.

\section{Data Bahasa Sumber Bahasa Sasaran 01 - Khotbah Di Bukit}

Pada data nomor 01 tidak terdapat data sumber, namun penerjemah menambahkan sub-judul 'Khotbah Di Bukit'. Penambahan ini dilakukan dengan maksud untuk memperjelas maksud penulis asli. Penerjemah berusaha mengeksplisitkan pesan di dalam bahasa sasaran.

Amplifiksi (amplification) adalah teknik penerjemahan yang digunakan penerjemah untuk mengeksplisitkan atau memparafrase suatu informasi yang implisit dalam bahasa sumber. Teknik amplikasi ini mirip dengan teknik addition, atau gain. Contoh berikut mempertegas hal tersebut.

$\begin{array}{lll}\text { Data } & \text { Bahasa Sumber } & \text { Bahasa Sasaran } \\ 05 & \text { "Blessed are } & \text { "Berbahagialah } \\ \text { the poor in spirit, } & \text { orang yang miskin } \\ & \begin{array}{l}\text { For theirs is } \\ \text { the kingdom of }\end{array} & \text { di hadapan Allah, } \\ \text { heaven. } & \text { yang empunya } \\ & & \text { Kerajaan Sorga. }\end{array}$

Penerapan teknik amplifikasi dimaksudkan untuk memberikan informasi yang lebih lengkap. Penerjemah mencoba mengeksplisitkan makna yang implisit ke dalam bahasa sasaran. Hal itu tampak ketika theirs dialihkan menjadi 'merekalah yang empunya'; the poor in spirit menjadi 'orang yang miskin di hadapan Allah'.

Transposisi adalah teknik penerjemahan yang diterapkan penerjemah dengan mengubah kategori gramatikal. Teknik ini sama dengan teknik pergeseran kategori, struktur dan unit. Pergeseran kategori merujuk pada perubahan kelas kata ba- 
hasa sumber dalam bahasa sasaran. Dalam banyak kasus, pergeseran kelas kata dapat bersifat wajib (obligatory) dan bebas (optional). Pergeseran kategori yang bersifat wajib dilakukan sebagai upaya untuk menghindari distorsi makna, sedangkan pergeseran kategori yang bersifat bebas pada umumnya diterapkan untuk memberikan penekanan topik pembicaraan dan untuk menunjukkan preferensi stilistik penerjemah.

Pergeseran unit merujuk pada perubahan satuan lingual bahasa sumber dalam bahasa sasaran. Pergeseran unit yang dimaksudkan dapat berbentuk pergeseran dari unit yang rendah ke unit yang lebih tinggi dan dari unit yang tinggi ke unit yang lebih rendah. Bahkan, pergeseran tersebut dapat pula berupa pergeseran dari konstruksi yang kompleks ke konstruksi yang sederhana dan dari konstruksi yang sederhana ke konstruksi yang kompleks.

Teknik transposisi dalam bentuk pergeseran struktur merupakan teknik yang paling lazim diterapkan apabila struktur bahasa sumber berbeda dari struktur bahasa sasaran. Oleh karena struktur bahasa Inggris dan struktur bahasa Indonesia berbeda, pergeseran struktur menjadi bersifat wajib (obligatory) agar terjemahan yang dihasilkan sesuai dengan kaidah-kaidah yang berlaku dalam bahasa Indonesia. Contoh berikut menjelaskan hal tersebut.

\section{Data Bahasa Sumber Bahasa Sasaran \\ 02 The Beatitudes Ucapan Bahagia}

Data sumber The Beatitudes yang menurut The Advanced Learner's Dictionary Current English, Hornby berarti great happiness; blessedness, yaitu 'kebahagiaan yang besar'; 'berkat' merupakan subjudul. Dalam menerjemahkan sub-judul ini, penerjemah menerapkan teknik transposisi, yaitu melakukan pergeseran unit, dari unit yang lebih kecil (beatitudes

= kata) ke unit yang lebih besar (ucapan bahagia=frasa). Kemudian juga terjadi pergeseran kategori yang merujuk pada perubahan kelas kata, yaitu beatitudes $=$ nomina menjadi ‘bahagia= kata sifat'

\section{Teknik Penerjemahan Kuplet}

Teknik kuplet yaitu perpaduan dua teknik penerjemahan yang diterapkan dalam menentukan padanan dalam bahasa sasaran. Dalam penelitian ini, teridentifikasi 10 varian teknik kuplet yang didominasi oleh perpaduan teknik transposisi dan modulasi, diikuti oleh perpaduan teknik amplifikasi dan modulasi, perpaduan teknik harfiah dan modulasi, perpaduan teknik modulasi dan reduksi, dan perpaduan teknik harfiah dan penghilangan. Frekuensi penggunaan varian teknik penerjemahan lainnya tergolong rendah. Deskripsi selengkapnya teknik kuplet disajikan pada Tabel 2.

Tabel 2. Teknik Penerjemahan Kuplet

\begin{tabular}{clc}
\hline Teknik & Varian Teknik Kuplet & Jumlah \\
\hline Kuplet & Transposisi + Modulasi & 37 \\
& Amplifikasi + Modulasi & 10 \\
& Harfiah+ Modulasi & 5 \\
& Modulasi + Reduksi & 4 \\
& Harfiah + Penghilangan & 3 \\
Transposisi + amplifikasi & 2 \\
Harfiah + Penambahan & 2 \\
Harfiah + Transposisi & 2 \\
Harfiah + Peminjaman & 2 \\
alamiah & \\
Transposisi + Reduksi & 1 \\
& Jumlah & 68 \\
\hline
\end{tabular}

Sebagaimana tampak pada Tabel 2, salah satu teknik penerjemahan adalah perpaduan antara teknik transposisi dan modulasi. Berikut adalah contoh penerapan teknik kuplet perpaduan transposisi dan modulasi.

Data Bahasa Sumber

044 "Nor shall you swear by your
Bahasa Sasaran Janganlah juga engkau bersumpah 
head, because demi kepalamu, you cannot make karena engkau one hair white tidak berkuasa or black. memutihkan atau menghitamkan sehelai rambut pun.

Pada contoh tersebut terlihat bahwa dalam pengalihan pesan bahasa sumber terjadi pergeseran struktur, yaitu dari kalimat berita Nor shall you swear by your head, menjadi kalimat perintah 'Janganlah juga engkau bersumpah demi kepalamu'; terjadi juga pergeseran kategori, yaitu dari kata sifat white dan black menjadi kata kerja 'memutihkan' dan 'menghitamkan'. Dengan menerapkan teknik modulasi penerjemah mengalihkan Nor shall you swear by your head menjadi 'Janganlah juga engkau bersumpah demi kepalamu'. Terjemahan ini mempunyai sudut pandang yang berbeda dengan pesan BSu karena pada bahasa sasaran berbentuk perintah sementara BSu tidak demikian. Lebih lanjut because you cannot make one hair white or black diterjemahkan menjadi ' $k a-$ rena engkau tidak berkuasa memutihkan atau menghitamkan sehelai rambut pun'. Terjemahan cannot make menjadi 'tidak berkuasa' tentunya berbeda dengan 'tidak dapat membuat'.

\section{Teknik Penerjemahan Triplet}

Teknik triplet merujuk pada perpaduan tiga teknik penerjemahan yang diterapkan dalam menerjemahkan data sumber. Dalam penelitian ini teridentifikasi 16 data dengan 6 varian yang diterjemahkan dengan menggunakan teknik penerjemahan triplet. Penerjemahan dengan paduan tiga teknik (kuplet) disajikan pada Tabel 3.
Tabel 3. Teknik Penerjemahan Triplet

\begin{tabular}{clc}
\hline Teknik & Varian Teknik Triplet & Jumlah \\
\hline Triplet & $\begin{array}{l}\text { Modulasi + Transposisi + } \\
\text { Amplifikasi }\end{array}$ & 10 \\
& $\begin{array}{l}\text { Modulasi + Transposisi + } \\
\text { Penghilangan } \\
\text { Amplifikasi + Modulasi + } \\
\text { Generalisasi }\end{array}$ & 2 \\
& $\begin{array}{l}\text { Peminjaman Alamiah + } \\
\text { Transposisi + Reduksi }\end{array}$ & 1 \\
& $\begin{array}{l}\text { Amplifikasi + Harfiah + } \\
\text { Modulasi }\end{array}$ & 1 \\
& $\begin{array}{l}\text { Harfiah + Peminjamahan } \\
\text { Alamiah + Amplifikasi }\end{array}$ & 1 \\
$\quad$ Jumlah
\end{tabular}

Salah satu teknik kuplet adalah perpaduan teknik modulasi, transposisi, dan amplifikasi. Berikut adalah contoh penerapan teknik triplet tersebut.

$\begin{array}{lll}\text { Data } & \text { Bahasa Sumber } & \text { Bahasa Sasaran } \\ \text { "But I tell you } & \text { Tetapi Aku } \\ \text { not to resist an } & \text { berkata kepadamu: } \\ \text { evil person. But } & \text { Janganlah kamu } \\ \text { whoever slaps } & \text { melawan orang } \\ \text { you on your right } & \text { yang berbuat jahat } \\ \text { cheek, turn the } & \text { kepadamu, } \\ \text { other to him also. } & \text { melainkan siapa } \\ & \text { pun yang menam- } \\ & \text { par pipi kananmu, } \\ & \text { berilah juga kepa- } \\ & \text { danya pipi kirimu. }\end{array}$

Penerapan ketiga teknik penerjemahan pada data 048 terlihat ketika penerjemah mengalihkan tell menjadi 'berkata' yang merupakan penerapan teknik modulasi karena terjadi perubahan sudut pandang yang bersifat leksikal. Not to resist dialihkan menjadi ‘Janganlah kamu melawan' merupakan penerapan teknik penerjemahan transposisi karena terjadi pergeseran dari frasa menjadi klausa. Penerapan teknik amplifikasi terlihat dengan penambahan kata 'kamu'. An evil person yang merupakan frasa nomina diterjemahkan dengan melakukan pergeseran unit menjadi klausa nomina 'orang yang 
berbuat jahat kepadamu' merupakan penerapan teknik transposisi. But whoever slaps you on your right cheek, turn the other to him also yang diterjemahkan menjadi 'melainkan siapa pun yang menampar pipi kananmu, berilah juga kepadanya pipi kirimu' merupakan penerapan teknik modulasi karena mengubah sudut pandang yang bersifat leksikal.

Selanjutnya, but yang seharusnya berarti 'tetapi' diterjemahkan menjadi 'melainkan', turn diterjemahkan menjadi 'berilah', sementara yang bersifat struktural terlihat dalam penerjemahan on your right cheek menjadi 'pipi kananmu'. Teknik transposisi diterapkan dengan melakukan pergeseran unit, seperti pada kata slaps menjadi frasa 'yang menampar'. Teknik amplifikasi diterapkan untuk mengeksplisitkan pesan dalam bahasa sasaran turn the other to him also menjadi 'berilah juga kepadanya pipi kirimu'.

\section{Teknik Penerjemahan Kuartet}

Teknik kuartet merupakan perpaduan empat teknik penerjemahan yang diterapkan dalam menerjemahkan data sumber ke dalam bahasa sasaran. Dalam penelitian ini teridentifikasi tiga data yang diterjemahkan dengan menerapkan teknik penerjemahan kuartet. Deskripsi lengkap disajikan pada Tabel 4 .

Tabel 4. Teknik Penerjemahan Kuartet

\begin{tabular}{clc}
\hline Teknik & Varian Teknik Kuartet & Jumlah \\
\hline Kuartet & Harfiah+ Amplifikasi+ & 1 \\
& Peminjaman & \\
& Alamiah+Modulasi \\
& Harfiah+Amplifikasi \\
& + Transposisi+Modulasi \\
& Modulasi + Transposisi+ \\
& Harfiah+ Penghilangan \\
& Jumlah & 3 \\
\hline
\end{tabular}

Salah satu teknik penerjemahan kuartet, yaitu harfiah+ amplifikasi+ peminjaman alamiah+modulasi. Penerapan teknik kuartet tersebut dapat dilihat dalam contoh berikut.

\begin{tabular}{|c|c|c|}
\hline \multirow{9}{*}{$\begin{array}{l}\text { Data } \\
024\end{array}$} & Bahasa Sumber & Bahasa Sasaran \\
\hline & "For I say to you, & Maka Aku berka \\
\hline & that unless your & kepadamu: Jika \\
\hline & righteousness & $\begin{array}{l}\text { hidup keagamaan } \\
\text { ahli-ahli Taurat }\end{array}$ \\
\hline & $\begin{array}{l}\text { exceeds the } \\
\text { righteousness of }\end{array}$ & $\begin{array}{l}\text { ahli-ahli Taurat } \\
\text { dan orang-orang }\end{array}$ \\
\hline & the scribes and & Farisi, sesunggu \\
\hline & Pharisees, you & nya kamu tidak \\
\hline & $\begin{array}{l}\text { eans } \\
\text { gdom }\end{array}$ & \\
\hline & of heaven. & Sorga. \\
\hline
\end{tabular}

Pada data 024 teknik penerjemahan harfiah diterapkan dalam mengalihkan data sumber for menjadi 'maka'; your righteousness exceeds the righteusness of the scribes and Pharisees menjadi 'jika hidup keagamaanmu tidak lebih benar daripada hidup keagamaan ahli-ahli Taurat dan orang-orang Farisi'; you will by no means menjadi 'sesungguhnya kamu tidak akan'. Penerapan teknik modulasi tampak dari perubahan sudut pandang dalam bahasa sasaran seperti for diterjemahkan menjadi 'maka'; righteusness diterjemahkan menjadi 'hidup keagamaan'. Teknik penerjemahan peminjaman alamiah tampak penerjemah menaturalisasi nama Pharisees menjadi 'Farisi'. Teknik penerjemahan amplifikasi tampak jelas dalam penerjemahan unless your righteousness exceeds the righteousness of the scribes and Pharisees, you will by no means enter the kingdom of heaven menjadi ' jika hidup keagamaanmu tidak lebih benar daripada hidup keagamaan ahli-ahli Taurat dan orang-orang Farisi, sesungguhnya kamu tidak akan masuk ke dalam Kerajaan Sorga.' Dalam menerjemahkan data ini, penerjemah mengeksplisitkan informasi dalam bahasa sasaran agar terjemahan dapat berterima oleh pembaca sasaran.

Berdasarkan uraian di atas, disimpulkan bahwa dari keseluruhan data penelitian diketahui bahwa teknik modulasi merupakan teknik yang paling banyak digunakan dalam proses penerjemahan. Deskripsi frekuensi teknik penerjemahan selengkapnya disajikan pada Tabel 5. 
Tabel 5. Frekuensi Penggunaan Teknik Penerjemahan

\begin{tabular}{clccccc}
\hline No & Teknik Penerjemahan & \multicolumn{2}{c}{ Varian Teknik } & Jumlah \\
& & Tunggal & Kuplet & Triplet & Kuartet & \\
\hline 1. & Modulasi & 24 & 55 & 14 & 3 & 96 \\
2. & Transposisi & 3 & 42 & 13 & 2 & 60 \\
3. & Harfiah & 6 & 14 & 2 & 3 & 25 \\
4. & Amplifikasi & 4 & 11 & 12 & 2 & 29 \\
5. & Penghilangan & 10 & 3 & 2 & 1 & 16 \\
6. & Penambahan & 4 & 2 & - & - & 6 \\
7. & Reduksi & - & 5 & 1 & - & 6 \\
8 & Peminjaman Alamiah & - & 2 & 2 & 1 & 5 \\
9. & Generalisasi & - & - & 1 & - & 1 \\
\hline
\end{tabular}

Tabel 6 Orientasi Teknik Penerjemahan

\begin{tabular}{clccc}
\hline Orientasi & \multicolumn{1}{c}{ Teknik Penerjemahan } & & Jumlah & Presentase \\
\hline Bahasa Sumber & Harfiah & 25 & 30 & $12.295 \%$ \\
& Peminjaman Alamiah & 5 & & \\
Bahasa Sasaran & Transposisi & 60 & 214 & $87.705 \%$ \\
& Penambahan & 6 & & \\
& Modulasi & 96 & & \\
& Penghilangan & 16 & & \\
& Amplifikasi & 29 & & \\
Reduksi & 6 & & \\
& Generalisasi & 1 & & \\
\hline
\end{tabular}

Dari kesembilan teknik penerjemahan sebagaimana disajikan pada Tabel 5, ditemukan ada dua teknik, yaitu teknik harfiah dan peminjaman alamiah berorientasi pada bahasa dan budaya bahasa sumber. Sementara itu, ada tujuh teknik, yaitu transposisi, modulasi, penghilangan, penambahan, amplifikasi, reduksi, dan generalisasi berorientasi pada bahasa dan budaya bahasa sasaran. Orientasi penerjemahan selengkapnya disajikan pada Tabel 6.

Tabel 6 menunjukkan bahwa secara keseluruhan, frekuensi kemunculan teknik penerjemahan yang berorientasi pada bahasa sumber sebanyak 30 kali (12.295\%), sedangkan frekuensi kemunculan teknik penerjemahan yang beroriensi pada bahasa sasaran sejumlah 214 kali (87.705\%). Dengan demikian dapat disimpulkan bahwa penerjemah menerapkan teknik penerjemahan yang berorientasi pada bahasa sasaran.
Berdasarkan penerapan teknik penerjemahan, yaitu teknik tunggal, kuplet, triplet, dan kuartet, tampak bahwa penerapan teknik penerjemahan ganda lebih dominan dibanding dengan teknik tunggal. Hal itu terkait dengan sifat teknik penerjemahan yang diarahkan pada tataran mikro. Dengan kata lain, teknik penerjemahan pada umumnya diterapkan pada satuan lingual yang berada di bawah tataran kalimat atau klausa. Kalimat atau klausa dibangun dari satuan lingual yang berada pada tataran mikro, teknik penerjemahan yang diterapkan dalam menerjemahkan kalimat atau klausa menjadi bervariasi.

Berdasarkan frekuensi kemunculannya atau penggunaannya pada keseluruhan data penelitian, teknik modulasi menempati urutan pertama yang diikuti oleh teknik transposisi, amplifikasi, harfiah, penghilangan, penambahan, reduksi, peminjaman alamiah, dan generalisasi. Tingginya penggunaan teknik modulasi, 
transposisi, dan amplifikasi dalam penelitian ini disebabkan oleh beberapa faktor sebagai berikut. Pertama, bahasa Inggris sebagai bahasa sumber dan bahasa Indonesia sebagai bahasa sasaran memiliki struktur yang berbeda. Oleh sebab itu perubahan sudut pandang, baik yang bersifat leksikal atau struktural, fokus atau kategori kognitif dalam kaitannya dengan teks sumber harus dilakukan melalui penerapan teknik penerjemahan modulasi dengan harapan terjemahan menjadi akurat dan berterima.

Dalam mengalihkan data sumber yang merupakan data agama haruslah jelas agar tidak terjadi kesalahpahaman bagi pembaca bahasa sasaran. Itulah sebabnya, penerjemah menggunakan teknik penerjemahan amplifikasi untuk mengeksplisitkan suatu informasi yang implisit dalam bahasa sumber dengan harapan hasil terjemahan dapat dengan mudah dipahami oleh pembaca bahasa sasaran. Hal ini sangat penting dilakukan karena data sumber merupakan ajaran agama yang wajib dimengerti dengan baik dan dilaksanakan oleh oleh umat.

Di samping memberikan dampak positif, terdapat juga penerapan teknik penerjemahan yang mempunyai dampak negatif bagi hasil terjemahan. Misalnya, penerapan teknik penghilangan total yang menyebabkan tidak lengkapnya pesan data sumber dalam data bahasa sasaran. Hal ini menyebabkan hasil terjemahan tidak akurat dan tidak berterima. Hasil terjemahan yang demikian tentunya berakibat fatal bagi pembaca bahasa sasaran karena teks terjemahan merupakan teks ajaran agama yang memberikan tuntunan bagi para umatnya.

Teks agama yang dikaji dalam penelitian ini dihasilkan oleh penerjemah karena ada pihak yang membutuhkan, yaitu para pemuka agama dan para umat. Merekalah yang menjadi pembaca sasaran yang ideal (ideal target readers atau designed target readers) dari teks terjemahan tersebut. Para pembaca sasaran ideal tersebut adalah orang Indonesia dengan kebudayaan yang tidak sama dengan pembaca bahasa sumber. Oleh karena itu, penerapan teknik penerjemahan yang berorientasi pada bahasa sasaran seperti teknik penerjemahan modulasi, transposisi, dan amplifikasi, merupakan langkah yang tepat. Hal itu sejalan dengan pemikiran Ruuskanen (1996) bahwa keputusan yang diambil penerjemah secara tidak langsung akan dipengaruh oleh pembaca sasaran.

Selain teknik yang berorientasi pada bahasa sasaran, penerjemah juga menerapkan teknik yang berorientasi pada bahasa sumber seperti teknik harfiah dan peminjaman alamiah. Hasil analisis menunjukkan bahwa penerapan teknik penerjemahan seperti teknik penerjemahan transposisi, modulasi, dan amplifikasi bersifat wajib (obligatory). Sementara itu, penerapan teknik penerjemahan penghilangan, reduksi, penambahan, dan peminjaman alamilah bersifat mana suka (optional). Bahkan penerapan teknikteknik penerjemahan tersebut cenderung merupakan preferensi stilistik (stylistic preference) penerjemah.

Terlepas dari teknik penerjemahan apapun yang diterapkan oleh penerjemah, tujuannya selalu terarah pada keinginan untuk menghasilkan terjemahan yang berkualitas, suatu terjemahan yang akurat dari segi pesannya, berterima dan mudah dipahami oleh pembaca sasaran. Dalam kaitan dengan itu, Beekman dan Callow (1974) menyatakan bahwa setiap bahasa mempunyai ciri-ciri tersendiri 'sui generis'. Setiap bahasa memiliki ciri yang berbeda dari bahasa lain yang akhirnya memicu terjadinya pergeseran (Catford, 1974:27).

Sebagai akibat dipentingkannya kesepadanan, dalam penerjemahan seringkali dilakukan pergeseran formal (struktur), yang mencakup: tataran morfem, sintaksis, pergeseran kategori kata (Simatupang 2000:77). Pada konteks tertentu tidak jarang terjadi pergeseran semantis 
(Machali, 2000: xi), sebab terjemahan bukan sesuatu yang statis, melainkan dinamis (Newmark, 1988). Bahkan menurut Bell (1991:6) ada sesuatu yang hilang dan ditambah dalam proses penerjemahan. Informasi yang ditambahkan biasanya bersifat kultural (Newmark, 1998:91) dan dipandang sebagai penjelasan tambahan untuk konsep-konsep khusus budaya dan bersifat wajib untuk tujuan keterbacaan (Baker, 1992). Sementara itu, penghilangan kata tertentu dapat dilakukan agar sesuai pola semantik dan gramatikal bahasa sasaran

Penelitian ini menunjukkan bahwa tidak semua teknik dipergunakan dalam menerjemahkan teks sumber ke dalam bahasa sasaran. Hal ini tentunya dengan berbagai pertimbangan seperti keakuratan, keberterimaan, dan keterbacaan teks keagamaan tersebut.

\section{Metode Penerjemahan}

Istilah metode menurut Machali (2000:48) berasal dari kata method dalam bahasa Inggris. Dalam Macquarie Dictionary (1982), a method is a way of doing something, especially in accordance with a definite plan. Dari uraian di atas dapat ditarik dua hal penting. Pertama, metode adalah cara melakukan sesuatu, yaitu 'cara melakukan penerjemahan'. Kedua, metode berkenaan dengan rencana tertentu, yaitu rencana dalam pelaksanaan penerjemahan.

Dalam penelitian ini ditemukan empat metode penerjemahan yang diterapkan, yaitu: (a) metode penerjemahan bebas, (b) komunikatif, (c) adaptasi, dan (d) harfiah. Berdasarkan frekuensi kemunculannya atau penggunaannya pada keseluruhan data penelitian ini diketahui bahwa metode penerjemahan bebas menempati urutan pertama, diikuti oleh metode komunikatif, adaptasi, dan harfiah. Dari keempat metode penerjemahan di atas, metode harfiah berorientasi pada bahasa dan budaya bahasa sumber, sedangkan tiga metode lainnya berorientasi pada bahasa dan budaya bahasa sasaran. Deskripsi selengkapnya disajikan pada Tabel 7.

Tabel 7. Orientasi Metode Penerjemahan

\begin{tabular}{clcc}
\hline Orientasi & \multicolumn{1}{c}{ Metode } & Jumlah & Presentase \\
\hline Bahasa & Harfiah & 7 & $5.65 \%$ \\
Sumber & & & \\
Bahasa & Bebas & 53 & $94.35 \%$ \\
Sasaran & Komunikatif & 51 & \\
& Adaptasi & 13 & \\
& Jumlah & 124 & \\
\hline
\end{tabular}

Tabel 7 menunjukkan bahwa secara keseluruhan, metode penerjemahan yang berorientasi pada bahasa sumber digunakan sebanyak $5.65 \%$, sedangkan frekuensi kemunculan metode penerjemahan yang beroriensi pada bahasa sasaran adalah $94.35 \%$. Metode penerjemahan yang dimaksud adalah metode penerjemahan bebas yang paling dominan diikuti oleh metode komunikatif, dan adaptasi. Sementara itu, metode penerjemahan yang berorientasi pada bahasa sumber, yaitu metode harfiah menduduki tempat terakhir. Dengan demikian dapat disimpulkan bahwa penerjemah menerapkan metode penerjemahan yang berorientasi pada bahasa sasaran. Penetapan metode penerjemahan tersebut sejalan dengan penerapan teknik penerjemahan. Berikut ini ditampilkan salah satu metode penerjemahan bebas.

Data Bahasa Sumber Bahasa Sasaran

019 "Let your light so Demikianlah shine before men, hendaknya that they may see terangmu bercayour good works haya di depanmu and glorify your orang, supaya Father in heaven. supaya mereka melihat perbuatanmu yang baik dan memuliakan Bapamu yang di sorga. 
Pada data 019 dari bahasa sumber "Let your light so shine before men"diterjemahkan menjadi 'Demikianlah hendaknya terangmu bercahaya di depan orang'. Terjemahan itu tidak terikat pada padanan kata atau kalimat Bsu. Penerjemah menyampaikan pesan data sumber ke dalam bahasa sasaran dengan memparafrase dengan tetap setia pada makna bahasa sumber. Demikian juga "that they may see your good works and glorify your Father in heaven"diterjemahkan menjadi "supaya mereka melihat perbuatanmu yang baik dan memuliakan Bapamu yang di sorga'. Dalam menerjemahkan data ini, penerjemah tidak terikat pada pencarian padanan pada tataran kata atau kalimat. Pencarian padanan cenderung berlangsung pada tataran teks seperti may see diterjemahkan menjadi 'melihat'; your good works menjadi 'perbuatanmu yang baik'; your Father in heaven yang berarti 'Bapamu di sorga', diterjemahkan menjadi 'Bapamu yang di sorga'.

Newmark (1988:4) mengemukakan bahwa pemilihan metode dibatasi oleh aspek-aspek yang mempengaruhi teks bahasa sasaran itu sendiri yaitu faktor pembaca bahasa sasaran, norma bahasa dan kebudayaan, dan fungsi terjemahan. Mengingat komunikasi penerjemahan berlangsung sebagai hasil dari mediasi pihak ketiga dalam hal ini penerjemah, faktor penerjemah juga mempengaruhi produk yang dihasilkan. Penerjemah sebagai agen komunikator memiliki cara pandang tersendiri terhadap teks yang dihadapinya. Cara pandang itu kemudian diwujudkan dengan interpretasinya tentang pesan-pesan teks sumber melalui pengalaman dan simpanan informasi yang ada di memorinya (Hatim dan Mason, 1990, 1997). Selain itu, faktor sosiokultural yang ada saat proses penerjemahan berlangsung juga mempengaruhi sebuah terjemahan.

Di atas semua itu, pemilihan metode penerjemahan yang seperti itu lebih didasarkan pada sifat teks bahasa sumber sebagai suatu teks yang sangat sensitif. Teks keagamaan yang menjadi sumber data penelitian ini termasuk teks yang beresiko tinggi. Hal-hal yang dibahas di dalamnya terkait langsung dengan ajaran agama yang harus dipahami dan dijalankan oleh umat. Kesalahan-kesalahan dalam menerjemahkanakan menimbulkan petaka bagi umat beragama. Oleh sebab itu, tidaklah mengherankan jika penerjemah cenderung menerapkan teknik modulasi, transposisi, dan amplifikasi untuk memudahkan pembaca bahasa sasaran dalam memahami teks terjemahan. Penerjemah berusaha mengorientasikan terjemahannya pada bahasa sasaran sebagai upaya untuk menyesuaikan dengan budaya dan struktur bahasa sasaran.

\section{Idiologi Penerjemahan.}

Ideologi adalah gagasan, sudut pandang, mitos dan prinsip yang dipercaya kebenarannya oleh kelompok masyarakat. Ideologi juga merupakan nilai-nilai budaya yang disepakati dan dimiliki oleh kelompok masyarakat dan berfungsi sebagai landasan dalam berpikir dan bertindak. Ideologi merupakan suatu konsep yang relatif karena kasus 'sesuatu' yang dipandang benar dalam suatu kelompok masyarakat bisa juga dipahami sebagai 'sesuatu' yang salah dalam kelompok masyarakat lainnya.

Dalam konteks aktivitas penerjemahan, idiologi berkaitan dengan kepada 'siapa' dan 'untuk tujuan apa' suatu terjemahan dilakukan. Terjemahan yang benar tergantung ideologi yang dianut. Aktivitas penerjemahan sering sekali ditentukan oleh sesuatu di luar teks itu sendiri dan juga menempatkan penerjemahan sebagai bagian kebudayaan masyarakat. Dengan kata lain, ideologi dalam penerjemahan memberi pandangan supermakro dalam membahas penerjemahan sebagai bagian dari kegiatan sosial budaya dan karya terjemahan sebagai bagian dari kebudayaan suatu masyarakat (Hoed, 2003). 
Lebih lanjut diungkapkan Hoed (2003) bahwa dalam bidang penerjemahan, ideologi adalah prinsip atau keyakinan tentang 'benar atau salah'. Bagi sebagian penerjemah, suatu terjemahan dianggap benar jika terjemahan tersebut telah secara utuh mengandung pesan teks bahasa sumber. Masalah keberterimaan terjemahan bagi pembaca sasaran kemudian menjadi sesuatu yang terabaikan. Ada pula penerjemah yang melegitimasi suatu terjemahan dengan berpedoman hanya pada kesusuaian terjemahan dengan kaidah, norma, dan budaya yang berlaku dalam bahasa sasaran. Kedua prinsip tersebut melahirkan dua kutub ideologi penerjemahan. Kutub pertama yaitu ideologi foreignisasi (foreignization) dan kutub yang kedua adalah ideologi domestikasi (domestication).

Pertama, ideologi foreignisasi berorientasi pada budaya dan bahasa sumber. Para penerjemah yang menganut foreignisasi berupaya untuk mempertahankan apa yang asing dan tidak lazim bagi pembaca sasaran tetapi merupakan hal yang lazim, unik, dan khas dalam budaya sumber. Dalam hal ini, terjemahan yang baik adalah terjemahan yang tetap mempertahankan gaya dan cita rasa kultural budaya sumber. Penerapan ideologi foreignisasi diwujudkan melalui penggunaan metode penerjemahan kata demi kata, penerjemahan harfiah, penerjemahan setia, dan/ atau penerjemahan semantik. Dari aspek pemadaman, ideologi foreignisasi sangat tergantung pada pemadanan formal (formal equivalence).

Kedua, ideologi domestikasi berorientasi pada kaidah, norma dan budaya bahasa sasaran. Oleh karena itu, penerjemah perlu mengetahui mengapa suatu teks diterjemahkan dan apa fungsi dari teks terjemahan tersebut. Setiap teks yang dihasilkan pasti mempunyai tujuan tertentu dan teks tersebut harus bisa memenuhi tujuan tersebut. Penerapan ideologi domestikasi akan tampak pada penggunaan metode penerjemahan adaptasi, penerjemahan bebas, penerjemahan idiomatis dan/atau penerjemahan komunikatif. Sementara itu, dalam hal pemadanan, ideologi domestikasi sangat bertumpu pada pemadanan dinamis ( $d y$ namic equivalence).

Kedua ideologi penerjemahan mempunyai orientasi yang bertolak belakang satu sama lain. Hal itu menunjukkan adanya kecenderungan bagi seorang penerjemah untuk menerapkan salah satu dari dua ideologi tersebut. Perhatikan contoh berikut ini.

$\begin{array}{lll}\text { Data } & \text { Bahasa Sumber } & \text { Bahasa Sasaran } \\ 083 & \text { "For where your } & \text { Karena di mana } \\ \text { treasure is, there } & \text { hartamu berada, } \\ \text { your heart will } & \text { disitu juga hatimu } \\ \text { be also. } & \text { berada. }\end{array}$

Data 083 diterjemahkan dengan menerapkan idelogi foreignisasi. Dalam hal ini penerjemah tetap patuh pada struktur bahasa sumber, seperti terlihat pada klausa "where your treasure is" yang tetap diterjemahkan dalam bentuk klausa "di mana hartamu berada", "there your heart will be also" diterjemahkan menjadi "disitu juga hatimu berada". Artinya, penerjemah tetap patuh pada struktur bahasa sumber.

Pada kutipan data 03 proses penerjemahan menerapkan idiologi domestifikasi. Perhatikan contoh berikut.

Data Bahasa Sumber

03 And seeing the multitudes, He went up on a mountain, and when He was seated His disciples came to Him.
Bahasa Sasaran Ketika Yesus me- lihat orang banyak itu, naiklah Ia ke atas bukit dan setelah Ia duduk, datanglah murid- murid-Nya kepada-Nya.

Pada data 03 penerjemah mengalihkan And seeing the multitudes menjadi 'Ketika 
Yesus melihat orang banyak itu'. Dalam menerjemahkan data ini, penerjemah tidak patuh pada konstruksi gramatikal bahasa sumber, tetapi disesuaikan dengan bahasa sasaran. Frasa dalam bahasa sumber menjadi klausa dalam bahasa sasaran dengan menambahkan subjek 'Yesus'. Demikian juga kata penghubung And dialihkan menjadi kata keterangan waktu 'Ketika'. Dalam menerjemahkan He went up on a mountain menjadi 'naiklah Ia ke atas bukit', penerjemah meletakkan kata kerja di depan subjek dan menerjemahkan mountain menjadi 'bukit'. Klausa when He was seated His disciples came to Him diterjemahkan menjadi 'setelah Ia duduk, datanglah murid-murid-Nya kepadanya'. Penerjemah mengalihkan kata when menjadi 'setelah', kata sifat was seated menjadi kata kerja 'duduk'. Dalam menerjemahkan klausa His disciples came to Him, penerjemah meletakkan kata kerja di depan subjek.

Berdasarkan frekuensi penggunaannya pada keseluruhan data penelitian ini teridentifikasi ideologi penerjemahan domestikasi menempati urutan pertama diikuti oleh ideologi foreignisasi pada urutan kedua. Deskripsi terperinci orientasi idiologi penerjemahan disajikan pada Tabel 8.

Tabel 8. Orientasi Ideologi Penerjemahan

\begin{tabular}{llcc}
\hline Orientasi & $\begin{array}{c}\text { Ideologi } \\
\text { Penerjemahan }\end{array}$ & Jumlah & Presentase \\
\hline $\begin{array}{c}\text { Bahasa } \\
\begin{array}{c}\text { Sumber } \\
\text { Bahasa }\end{array}\end{array}$ & Foreignisasi & 7 & $5.65 \%$ \\
Sasaran & Domestikasi & 117 & $94.35 \%$ \\
& Jumlah & & \\
\hline
\end{tabular}

Tabel 8 menunjukkan bahwa secara keseluruhan ideologi penerjemahan yang berorientasi pada bahasa sumber digunakan sebanyak $5.65 \%$, sedangkan frekuensi kemunculan ideologi penerjemahan yang beroriensi pada bahasa sasaran adalah $94.35 \%$. Dengan demikian dapat disim- pulkan bahwa penerjemah menganut ideologi penerjemahan yang berorientasi pada bahasa sasaran.

Hasil penelitian ini menunjukkan terdapat dua ideologi penerjemahan yang melandasi proses pengambilan keputusan yang dilakukan penerjemah, yaitu ideologi foreignisasi dan domestikasi. Munculnya kedua ideologi tersebut mencerminkan adanya konflik batin dalam diri penerjemah. Di satu sisi, penerjemah ingin mempertahankan isi pesan teks bahasa sumber sesetia mungkin dalam teks bahasa sasaran. Di sisi lain, penerjemah juga ingin terjemahannya berterima dan mudah dipahami oleh pembaca sasaran. Analisis data secara keseluruhan menunjukkan bahwa penerjemah cenderung menerapkan ideologi domestikasi. Hal itu tercermin dari penerapan teknik penerjemahan modulasi, transposisi, dan amplifikasi. Demikian juga penerapan motode penerjemahan bebas, komunikatif, dan adaptasi yang dominan. Di kalangan para pakar penerjemahan teknik-teknik penerjemahan dan metode-metode penerjemahan tersebut dikategorikan sebagai teknik dan metode yang berorientasi pada bahasa sasaran.

\section{Kualitas Hasil Terjemahan}

Penerjemahan sebagai proses pengambilan keputusan dalam peristiwa komunikasi interlingual dipahami sebagai proses pemecahan masalah padanan yang dilandasi dan dipengaruhi sistem nilai dan sudut pandang penerjemah. Dengan kata lain, pemilihan teknik dan metodepenerjemahan tidak bisa dilepaskan dari ideologi yang dianut penerjemah. Ketiga hal tersebut sangat berpengaruh pada hasil terjemahan.

Kualitas hasil terjemahan dapat dianalogikan dengan tiga sisi mata uang logam. Sisi pertama merupakan sisi keakuratan pengalihan pesan. Sisi kedua merupakan sisi tingkat keberterimaan terjemahan dan sisi yang ketiga terkait 
dengan tingkat keterbacaan terjemahan. Keutuhan dari kualitas hasil suatu terjemahan tercermin dari kemunculan ketiga sisi tersebut.

Selanjutnya, kualitas terjemahan dapat ditinjau dari tiga indikator, yaitu (a) keakuratan pesan, (b) keberterimaan dan(c) keterbacaan terjemahan. Ketiga indikator diuraikan pada berikut ini.

Pertama, tingkat keakuratan terjemahan. Data sumber yang dialihkan ke dalam bahasa sasaran dapat dikategorikan ke dalam tiga kulaitas, yaitu: (1) terjemahan akurat, (2) terjemahan kurang akurat, dan (3) terjemahan tidak akurat. Terjemahan akurat merujuk pada terjemahan yang tidak mengalami distorsi makna. Dengan kata lain, makna kata, frasa, klausa, dan kalimat bahasa sumber dialihkan secara akurat ke dalam bahasa sasaran. Terjemahan kurang akurat merujuk pada terjemahan yang sebagian besar makna kata, frasa, klausa, atau kalimat bahasa sumber sudah dialihkan secara akurat ke dalam bahasa sasaran. Namun, masih terdapat distorsi makna atau terjemahan makna ganda (taksa) atau ada makna yang dihilangkan, yang mengganggu keutuhan pesan. Selanjutnya, terjemahan yang tidak akurat merujuk pada terjemahan yang makna kata, frasa, klausa atau kalimat bahasa sumber dialihkan secara tidak akurat ke dalam bahasa sasaran atau dihilangkan (deleted).

Dalam penelitian ini teridentifiksi 93 (68.12\%) data merupakan terjemahan yang akurat, 29 (21.01\%) data termasuk terjemahan yang kurang akurat dan 15 $(10.87 \%)$ data adalah terjemahan yang tidak akurat. Ketidakakuratan terjemahan disebabkan oleh pemadanan yang tidak tepat, penghilangan yang tidak perlu, penambahan informasi yang tidak perlu, dan pergeseran informasi yang menyebabkan distorsi makna.

Kedua, keberterimaan hasil terjemahan. Suatu terjemahan dikatakan berterima jika terjemahan memenuhi sejumlah kriteria. Kriteria yang dimaksud, yaitu: (a) hasil terjemahan terasa alamiah,(b) istilah yang digunakan lazim digunakan dan akrab bagi pembaca, dan (c) kata, frasa, klausa, dan kalimat yang digunakan sudah sesuai dengan kaidah-kaidah bahasa Indonesia. Terjemahan yang kurang berterima merujuk pada terjemahan yang pada umumnya sudah terasa alamiah, namun ada sedikit masalah pada penggunaan istilah teknis atau terjadi sedikit kesalahan gramatikal. Terjemahan tidak berterima identik dengan terjemahan tidak alamiah atau terasa seperti karya terjemahan. Data kata, frasa, klausa, dan kalimat yang digunakan tidak sesuai dengan kaidah-kaidah bahasa Indonesia. Dalam penelitian ini, teridentifikasi 97 data $(70 \%)$ dapat dikategorikan sebagai terjemahan berterima, 27 data $(20 \%)$ merupakan terjemahan kurang berterima, dan 14 data (10\%) merupakan terjemahan tidak berterima.

Ketiga, tingkat keterbacaan hasil terjemahan. Suatu terjemahan disebut mempunyai tingkat keterbacaan tinggi jika kata, frasa, klausa, dan kalimat terjemahan dapat dipahami dengan mudah oleh pembaca. Suatu terjemahan disebut mempunyai tingkat keterbacaan sedang apabila pada umumnya terjemahan dapat dipahami oleh pembaca; namun ada bagian tertentu yang harus dibaca lebih dari satu kali untuk memahami terjemahan. Dari hasil analisis data, diketahui bahwa 105 data (82\%) dapat dikategorikan sebagai terjemahan yang mempunyai tingkat keterbacaan tinggi, dan 23 data $(18 \%)$ merupakan terjemahan dengan tingkat keterbacaan sedang.

Seperti telah diungkapkan sebelumnya bahwa keterkaitan teknik, metode, dan ideologi penerjemahan akan berdampak pada kualitas terjemahan. Hasil penelitian ini menunjukkan teknik penerjemahan modulasi, transposisi, dan amplifikasi memberikan dampak positif terhadap keakuratan terjemahan. 
Sementara itu, kekurangakuratan dan ketidakakuratan yang terjadi pada terjemahan lebih disebabkan oleh penerapan teknik penghilangan secara menyeluruh atau total.Tampak jelas bahwa penerjemah mempunyai kompetensi bidang ilmu yang cukup baik tetapi hal itu tidak disertai oleh penguasaan yang baik terhadap bahasa sumber dan bahasa sasaran (language competence). Hal itu tercermin dari teknik penghilangan yang cenderung menghasilkan terjemahan yang tidak akurat dan tidak berterima. Pemanfaatan ideologi domestikasi, pemilihan metode penerjemahan, dan penggunaan teknikteknik penerjemahan yang berorientasi pada bahasa sasaran menunjukkan bahwa pengetahuan deklaratif dan operatif penerjemah cukup baik.

Pada umumnya proses penerjemahan yang dilandasi oleh ideologi domestikasi berdampak positif kepada tingkat keakuratan pesan, keberterimaan, dan keterbacaan terjemahan. Hasil penelitian menunjukkan hal yang sejalan, yaitu penerjemah cenderung menganut ideologi domestikasi dan terjemahan yang dihasilkannya tergolong akurat, berterima, dan mudah dipahami oleh pembaca bahasa sasaran.

\section{SIMPULAN}

Berdasarkan analisis teknik, metode, dan ideologi penerjemahan yang digunakan oleh penerjemah dalam menerjemahkan teks TheGospel According to Matthewke dalam teks Bahasa Indonesia dapat disimpulkan hal-hal berikut. Pertama, penerjemah cenderung menerapkan teknik penerjemahan yang berorientasi pada bahasa sasaran. Kedua, penerjemahan juga cenderung menerapkan metode penerjemahan yang berorientasi pada bahasa sasaran. Ketiga, penerjemah cenderung menganut ideologi domestikasi yang berorientasi pada bahasa sasaran. Keempat, penerapan teknik, motode, dan ideologi penerjemahan yang berorientasi pada ba- hasa sasaran memberikan dampak positif pada hasil terjemahan yang mencakup keakuratan pesan, keberterimaan, dan keterbacaan terjemahan.

\section{UCAPAN TERIMA KASIH}

Tulisan ini disarikan dari hasil penelitian disertasi pada Program Pascasarjana, Fakultas Ilmu Budaya, Universaitas Gadjah Mada Tahun 2013. Ucapan terima kasih penulis sampaikan kepada Prof. Dr. I Dewa Putu Wijana, S.U., M.A (promotor), Dr. F.X. Nadar, M.A (Ko Promotor) yang telah memberikan masukan-masukan dan telah membimbing dalam seluruh proses tahapan penelitian ini. Terima kasih juga ditujukan kepada Prof. Dr. Suminto A. Sayuti dan Dr. Wiyatmi, M.Hum yang telah memberi masukan, catatan penting, dan pembenahan aspek kebahasaan untuk penyempurnaan tulisan ini.

\section{DAFTAR PUSTAKA}

Baker, M. 1992. In Other Words: A Coursebook on Translation. London: Sage Publication.

Beekman, J., dan Callow, John. 1974. Translating The Word of God. Michigan: Zondervan

Brislin, Richard W. (ed). 1976. Translation Application and Research. New York: Gardner Press, Inc.

Catford, J.C. 1974. A Linguistic Theory of Translation. New York: Oxford University Press.

Hatim, Basil and Ian Mason. 1990. Discourse and The Translator. London and New York: Longman

Hoed, Benny Hoedoro. 2003. "Ideologi dalam Penerjemahan". Makalah disajikan dalam Seminar Nasional Penerjemahan, Tawangmangu. 15-16 September 2003.

Hoed, Benny Hoedoro. 2003. Penerjemahan dan Kebudayaan. Jakarta: Pustaka Jaya.

Hornby, A.S. 1973. The Advanced Learner's Dictionary Of Current English. (Second 
Edition) London: Oxford University Press.

Ihroni, T.O. 1984 (ed). Koentjaraningrat. Pokok-Pokok Antropologi Budaya. Jakarta: Gramedia.

Kennedy, D.James and Jerry Newcombe. 1999. Bagaimana Jika Alkitab Tidak Pernah Ditulis?. Batam Centre, Interaksara.

Larson, Mildred L. 1984. Meaning Based Translation, A Guide to Cross Language Equivalent. USA: University Press of America

Latuihamallo. 1994. Persebaran Firman Di Sepanjang Zaman. Jakarta: Lembaga Alkitab Indonesia dan PT BPK Gunung Mulia.

Lembaga Alkitab Indonesia. 2009. Holy Bible Idealline. Jakarta: Lembaga Alkitab Indonesia.

Lembaga Alkitab Indonesia. 2008. Alkitab. Jakarta: Lembaga Alkitab Indonesia.

Machali, Rochayah. 2000. Pedoman Bagi Penerjemah. Jakarta: PT Grasindo.
Machali, Rochayah.1998. Redefining Textual Equivalence in Translation. Jakarta: The University of Indonesia.

Newmark, Peter. 1988. Approaches to Translation. Cambridge: University Press.

Newmark, Peter. 1988. A Textbook of Translation. London: Prentice-Hall

Ruuskanen, D.D.K. 1996. "Creating the 'other': A Pragmatic Translation tool". In Dollerup, Cay, Appel, and Vibeke (eds.). Teaching Translation and Interpreting 3; New Horizons. Amsterdam: John Benjamins

Sayogya. 1982. Sosiologi Pedesaan Jilid I. Yogyakarta: Gadjah Mada UniversityPress.

Simatupang, Maurits. 2000. Pengantar Teori Terjemahan. Jakarta: Depdiknas

Supardan. 2004. Menerjemahkan Alkitab: Perjalanan Mencari Hikmat. Makalah padaSeminar Nasional, Lembaga Alkitab Indonesia, Jakarta.

Tjen, Anwar. 2004. Satu Alkitab, Banyak Versi: Mengapa? Makalah Seminar Nasional, Lembaga Alkitab Indonesia, Jakarta. 